\title{
Two new species of the jumping spiders (Araneae: Salticidae) from the genera Epeus Peckham et Peckham, 1886 and Piranthus Thorell, 1895 from India
}

\author{
Ава новых вида пауков-скакунчиков (Araneae: Salticidae) \\ из родов Epeus Peckham et Peckham, 1886 и Piranthus \\ Thorell, 1895 из Инаии
}

\section{Jobi J. Malamel ${ }^{1, *}$, Karunnappilli Shamsudheen Nafin ${ }^{2}$, Ambalaparambil V. Sudhikumar ${ }^{2}$, Pothalil A. Sebastian ${ }^{1}$ Ажкоби Аж. Маламе ${ }^{1, *}$, Каруннаппими Шамсудхин Нафин ${ }^{2}$, Амбалапарамбия В. Судхикумар ${ }^{2}$, Потхамиц А. Себастиан ${ }^{1}$}

\footnotetext{
${ }^{1}$ Division of Arachnology, Department of Zoology, Sacred Heart College, Thevara, Cochin, Kerala 682013 , India.

${ }^{2}$ Centre for Animal Taxonomy and Ecology, Department of Zoology, Christ College, Irinjalakuda, Kerala, 680 125, India.

* Corresponding author. E-mail: jomaljoseph@yahoo.co.in
}

KEY WORDS: Aranei, descriptions, Pathiramanal Island, Ramsar site, taxonomy, Western Ghats.

КЛЮЧЕВЫЕ СЛОВА: Aranei, описания, остров Патираманал, локалитет Рамсар, таксономия, Западные Гаты.

ABSTRACT. Two new species of the jumping spiders from different parts of India, collected from different expeditions, are diagnosed and described: viz., Epeus triangulopalpis sp.n. (O'O) and Piranthus planolancis sp.n. ( $(+)$. A detailed account of somatic and genitalic characters, digital images, $\mathrm{B} / \mathrm{W}$ illustrations and live photos are given. A map with collecting localities of these species is provided as well.

How to cite this article: Malamel J.J., Nafin K.Sh., Sudhikumar A.V., Sebastian P.A. 2019. Two new species of the jumping spiders (Araneae: Salticidae) from the genera Epeus Peckham et Peckham, 1886 and $P i$ ranthus Thorell, 1895 from India // Arthropoda Selecta. Vol.28. No.2. P.267-276. doi: 10.15298/arthsel. 28.2.10

РЕЗЮМЕ. Два вида пауков-скакунчиков из различных регионов Индии, собранных в различных экспедициях, диагностированы и описаны: а именно, Epeus triangulopalpis sp.n. ( $\left.{ }^{7}+\right)$ и Piranthus planolancis sp.n. (). Приводятся детальное описание соматических и генитальных признаков, черно-белые иллюстрации, цифровые фотографии и фотографии из природы. Также приводится карта с точками находов новых видов.

\section{Introduction}

During the survey of Indian spiders, we have discovered two new species of the genera Epeus Peckham et Peckham, 1886 and Piranthus Thorell, 1895. Species of the Oriental genus Epeus have the flattened and elongated cymbium in the male palp, with a retrolateral basal apophysis pointing postero-ventrad; the tegulum with a tongue-like process; the filiform embolus; and the epigyne with the long copulatory ducts having several loops [Meng et al. 2015]. Epeus currently comprises 15 valid species, of which the majority (nine species) have been reported from different parts of the Oriental Region. The remaining Epeus species extend their ranges to India, China and Nepal. The genus Piranthus Thorell, 1895 is represented by two species known from India and Myanmar [WSC, 2018], both remain known from the females only. Among them, $P$. casteti Simon, 1900 seems to be endemic to India, whereas $P$. decorus Thorell, 1895 was originally described from Myanmar but then had also been recorded from India [Caleb, Sanap, 2017]. Yet, Caleb \& Sanap [2017] provided digital images of a general appearance of an unknown Piranthus male, while no male of the described Piranthus species has been recorded/described yet.

In the present paper, we aim to describe two new species of Epeus and Piranthus based on newly collected materials from the coastal plains of Western Ghats and an estuarine island of southern India. Photos of live specimens of both species (Figs 1-6), as well as a map with collecting localities of the Epeus species in India and all the records of Piranthus are also provided.

\section{Material and methods}

The specimens were studied under a LEICA S8AP0 stereomicroscope. All measurements are in $\mathrm{mm}$. Palp and leg segment lengths are given as follows: (femur, patella, tibia, metatarsus (except palp), and tarsus) total. The micro- 

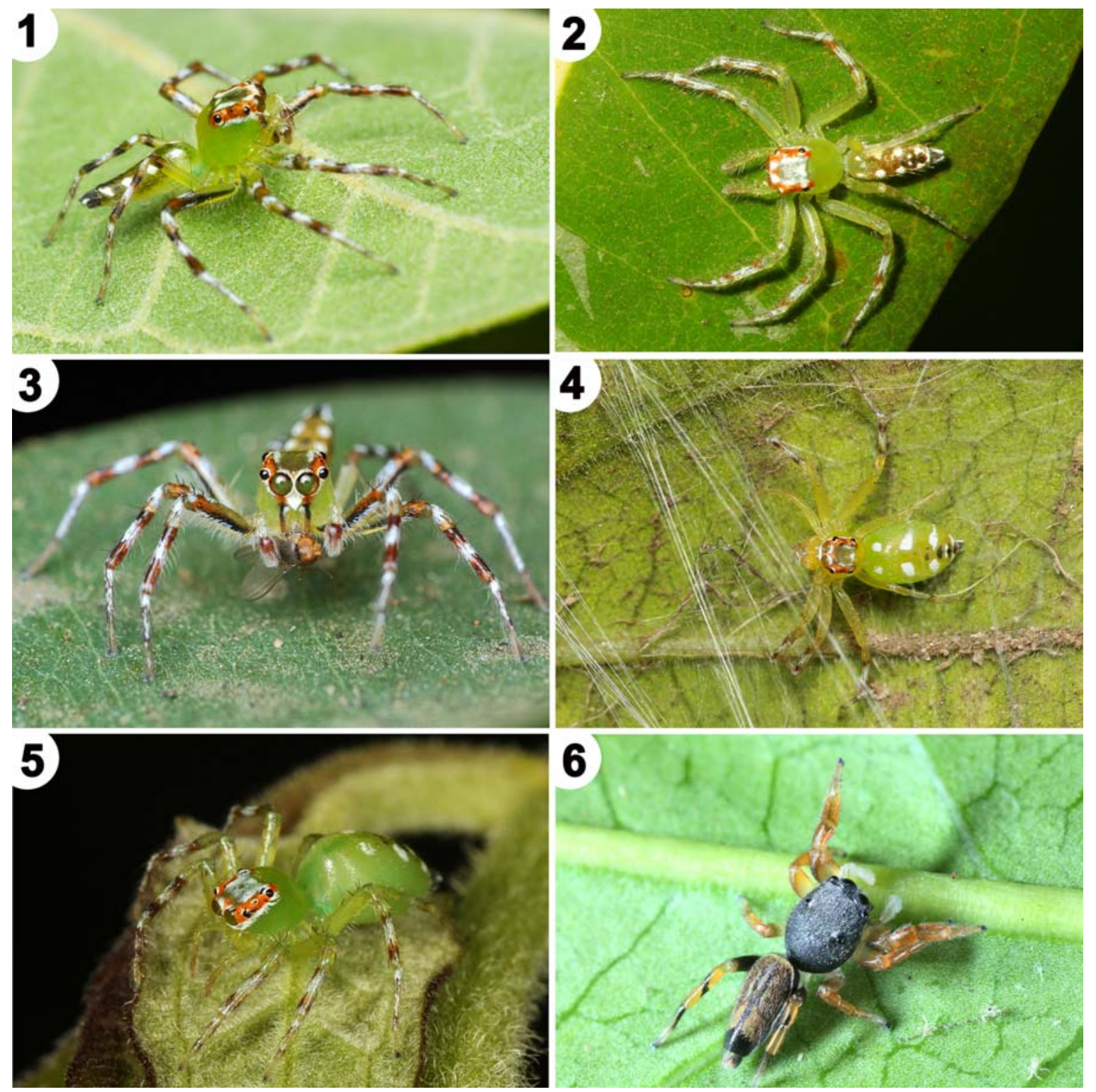

Figs 1-6. General appearance of Epeus triangulopalpis sp.n. (1-5) and Piranthus planolancis sp.n. (6): 1 - lateral view of the male from Kudan, Maharashtra; 2 - dorsal view of the male from Parambikulam Tiger Reserve, Kerala; 3 - ditto, frontal view; 4 - dorsal view of the female from Pathiramanal Island; 5 - ditto, lateral view; 6 - dorsal view of the female from Muriyad Kol wetlands, Kerala. Photo credits: 1,3 - Atul Vartak; 2, 4, 5, 6- K.S. Nafin.

Рис. 1-6. Общий вид Epeus triangulopalpis sp.n. (1-5) и Piranthus planolancis sp.n. (6): 1 - вид сбоку самца из Кудана, Махараштра; 2 - вид сверху самца из тигрового заведника Парамбикулам, Керала; 3 - то же, вид спереди; 4 - вид сверху самки с острова Патираманал; 5 - то же, вид сбоку; 6 - вид сверху самки с болот Мурьяд Кол, Керала. Фотографии: 1,3 - Атул Вартак; 2, 4, 5, 6 - К.С. Нафин.

photographic images were taken by means of Leica DFC2900 digital camera attached to a Leica M205A stereomicroscope with the software package Leica Application Suite (LAS), version 4.5.0. The studied specimens are deposited in the reference collection housed at the Division of Arachnology, Department of Zoology, Sacred Heart College, Thevara, Cochin, Kerala, India (ADSH) and the Centre for Animal Taxonomy and Ecology, Christ College, Irinjalakuda, Kerala (CATE).

Abbreviations used in the text are as follows: ALE anterior lateral eye, AME — anterior median eye, PLE - posterior lateral eye, PME - posterior median eye, I-IV 1 st to 4 th leg, $\mathrm{m}$ - meter.

\section{Descriptions}

Salticidae Blackwall, 1841

Epeus Peckham et Peckham, 1886

Type species: Epeus tener (Simon, 1877). 

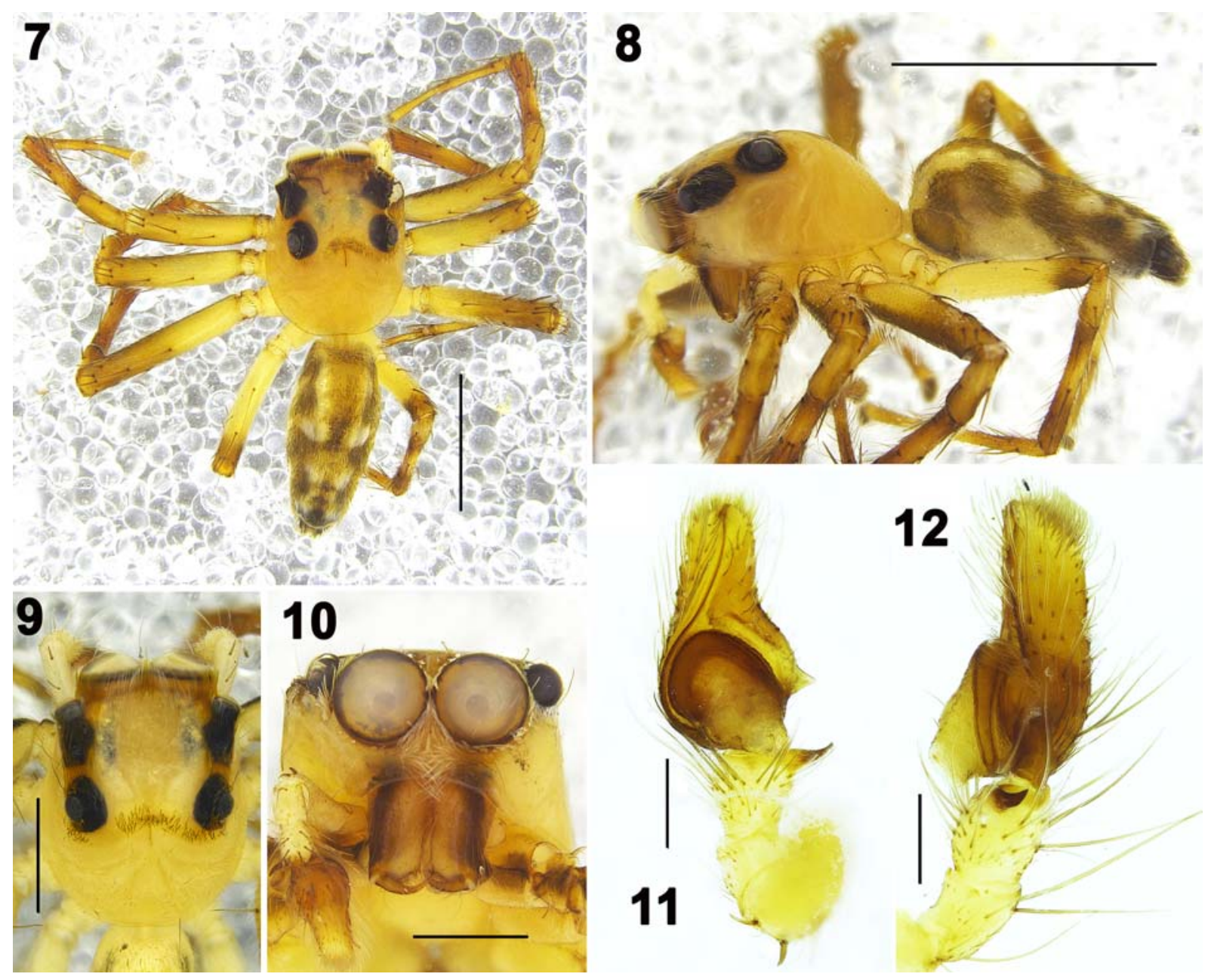

Figs 7-12. The holotype male of Epeus triangulopalpis sp.n.: 7 - general appearance, dorsal view; 8 - ditto, lateral view; 9 carapace, dorsal view; 10 - ditto, frontal view; 11 - palp, ventral view. 12 - ditto, retrolateral view. Scale bars: (7-8) 2 mm, (9-10) 1 $\mathrm{mm},(11-12) 0.5 \mathrm{~mm}$.

Рис. 7-12. Самец-голотип Epeus triangulopalpis sp.n.: 7 - общий вид сверху; 8 - то же, сбоку; 9 - головогрудь, вид сверху; 10 - то же, спереди; 11 - пальпа, вид снизу; 12 — то же, сбоку-сзади. Масштаб: (7-8) 2 мм, (9-10) 1 мм, (11-12) 0,5 мм.

DIAGNOSIS. The congeners of Epeus can be distinguished from other members of the tribe Plexippini by the following combination of characters [Song et al., 1988; Peng, Li, 2002]: carapace high and elevated; the palpal cymbium elongated and narrowing distally, with its basal cymbial apophysis extending ventrally to the tibial apophysis, except for E. alboguttatus (Thorell, 1887) and E. triangulopalpis sp.n.; the tegulum with a tongue-like flap; the embolus very long and thin, surrounding the semicircle of tegulum and extending to the distal end of the cymbium; the palpal tibia with a single apophysis; the epigyne with a shallow depression anteriorly; the spermathecae with long insemination ducts forming several loops.

\section{Epeus triangulopalpis sp.n.}

Figs 1-6, 7-12, 13-19, 20-23, Map.

TYPES. Holotype $0^{T}$ (ADSH, 86164A) from India, Kerala, Pathiramanal Island $\left(9^{\circ} 37^{\prime} 07.11^{\prime \prime} \mathrm{N}, 76^{\circ} 23^{\prime} 04.95^{\prime \prime} \mathrm{E}\right), 4 \mathrm{~m}$ a.s.l., 22.08.2015, M.J. Jobi \& P. Jimmy. PARATYPES: $10^{7}$ (ADSH 8716616A), the same locality as that of the holotype, 11.10.2015, M.J. Jobi \& P. Jimmy; $10^{7}, 1$ ( (CATE 8704A), Kerala, Irinjalaku- da, Christ college $\left(10^{\circ} 21^{\prime} 28^{\prime \prime} \mathrm{N}, 76^{\circ} 12^{\prime} 47^{\prime \prime} \mathrm{E}\right), 15 \mathrm{~m}$ a.s.l., from foliage by hand, 09-10.2015, A.V. Sudhikumar \& K S. Nafin.

OTHER MATERIAL. INDIA: 1 (CATE 8704B), Kerala, Bathery Range, Wayanad Wildlife Sanctuary $\left(11^{\circ} 40^{\prime} 48.3^{\prime \prime} \mathrm{N}, 76^{\circ} 20^{\prime}\right.$ $\left.38.1^{\prime \prime} \mathrm{E}\right), 850 \mathrm{~m}$ a.s.1., from foliage by hand, 17.06.2015, P.P. Sudhin \& K.S. Nafin; $10^{7}$ (CATE 8704C), Kerala, Parambikulam Tiger Reserve, Parambikulam $\left(10^{\circ} 23^{\prime} 53.3^{\prime \prime} \mathrm{N}, 76^{\circ} 46^{\prime} 29.3^{\prime \prime} \mathrm{E}\right), 585 \mathrm{~m}$ a.s.l., from foliage by hand, 22.09 .2014 , K.S. Nafin, P.P. Sudhin \& P. Jimmy; 1 (ADSH 8716616B), Kerala, Pathiramanal Island $\left(9^{\circ} 37^{\prime}\right.$ $\left.07.11^{\prime \prime} \mathrm{N}, 76^{\circ} 23^{\prime} 04.95^{\prime \prime} \mathrm{E}\right), 4 \mathrm{~m}$ a.s.1., 17.01.2018, Jithin \& Aneesh.

ETYMOLOGY. The specific name refers to the fact that the new species has the triangular cymbial apophysis.

DIAGNOSIS. The new species can be easily distinguished from its closest congener, E. alboguttatus, and all other Indian species by the following characters: the eye field in the males without a conical comb of long upright setae (a prominent comb of orange upright setae in $E$. alboguttatus); dorsum with four pairs of distinct white markings (a median dark grey streak in E. alboguttatus); the palpal cymbial apophysis triangular, directed laterad (markedly shorter and directed posteriad in E. alboguttatus); the insemination ducts form large lateral loops (such loops are 

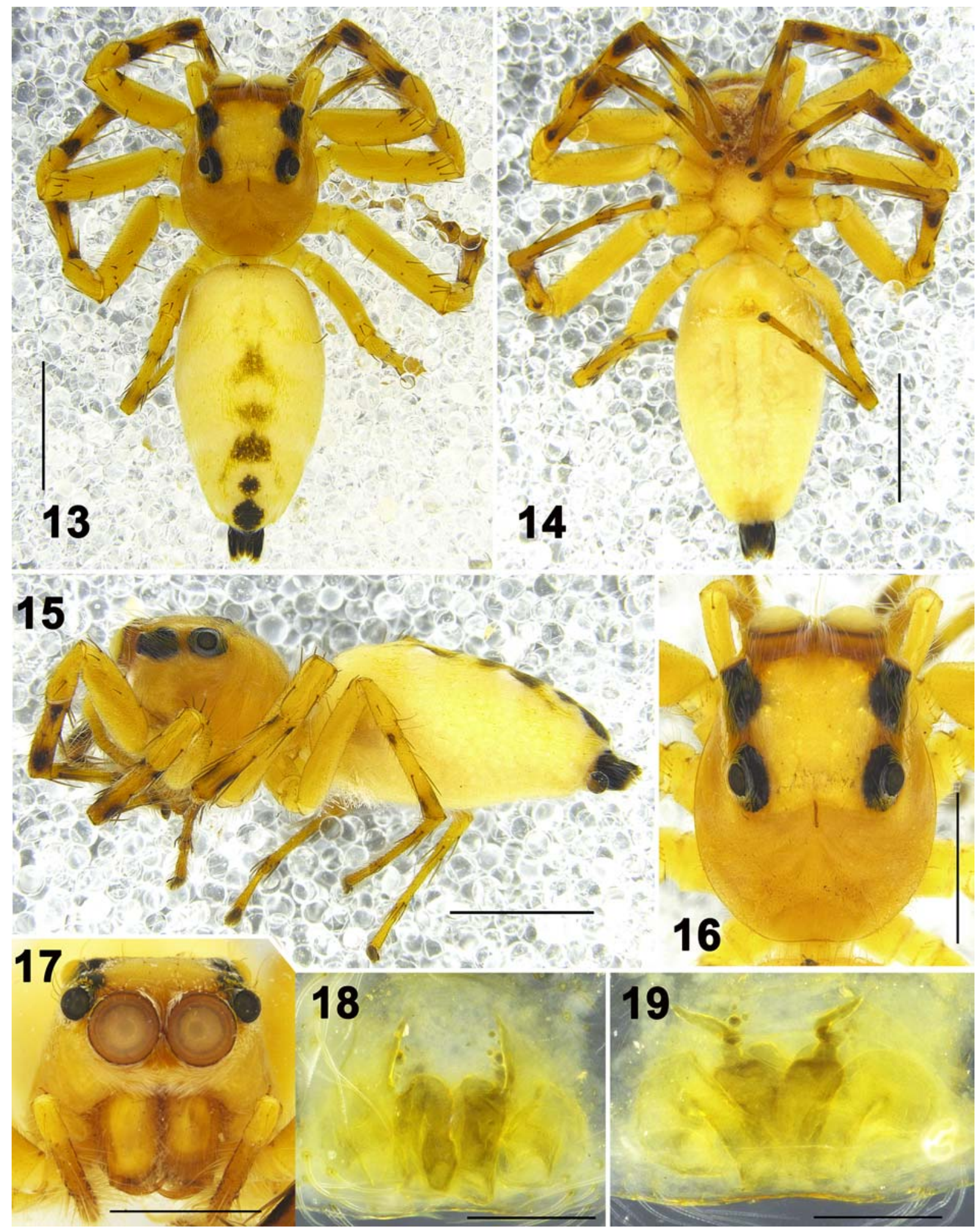

Figs 13-19. Female paratype of Epeus triangulopalpis sp.n.: 13 - general appearance, dorsal view; 14 - ditto, ventral view; 15 ditto, lateral view; 16 - carapace, dorsal view; 17 - ditto, frontal view; 18 - epigyne, ventral view; 19 - spermathecae, dorsal view. Scale bars: (13-15) $2 \mathrm{~mm},(16-17) 1 \mathrm{~mm},(18-19) 0.1 \mathrm{~mm}$.

Рис. 13-19. Самка-паратип Epeus triangulopalpis sp.n.: 13 - общий вид сверху; 14 - то же, снизу; 15 - то же, сбоку; 16 головогрудь, вид сверху; 17 - то же, спереди; 18 - эпигина, вид снизу; 19 - сперматека, сверху. Масштаб: (13-15) 2 мм, (1617) 1 мм, (18-19) 0,1 мм. 


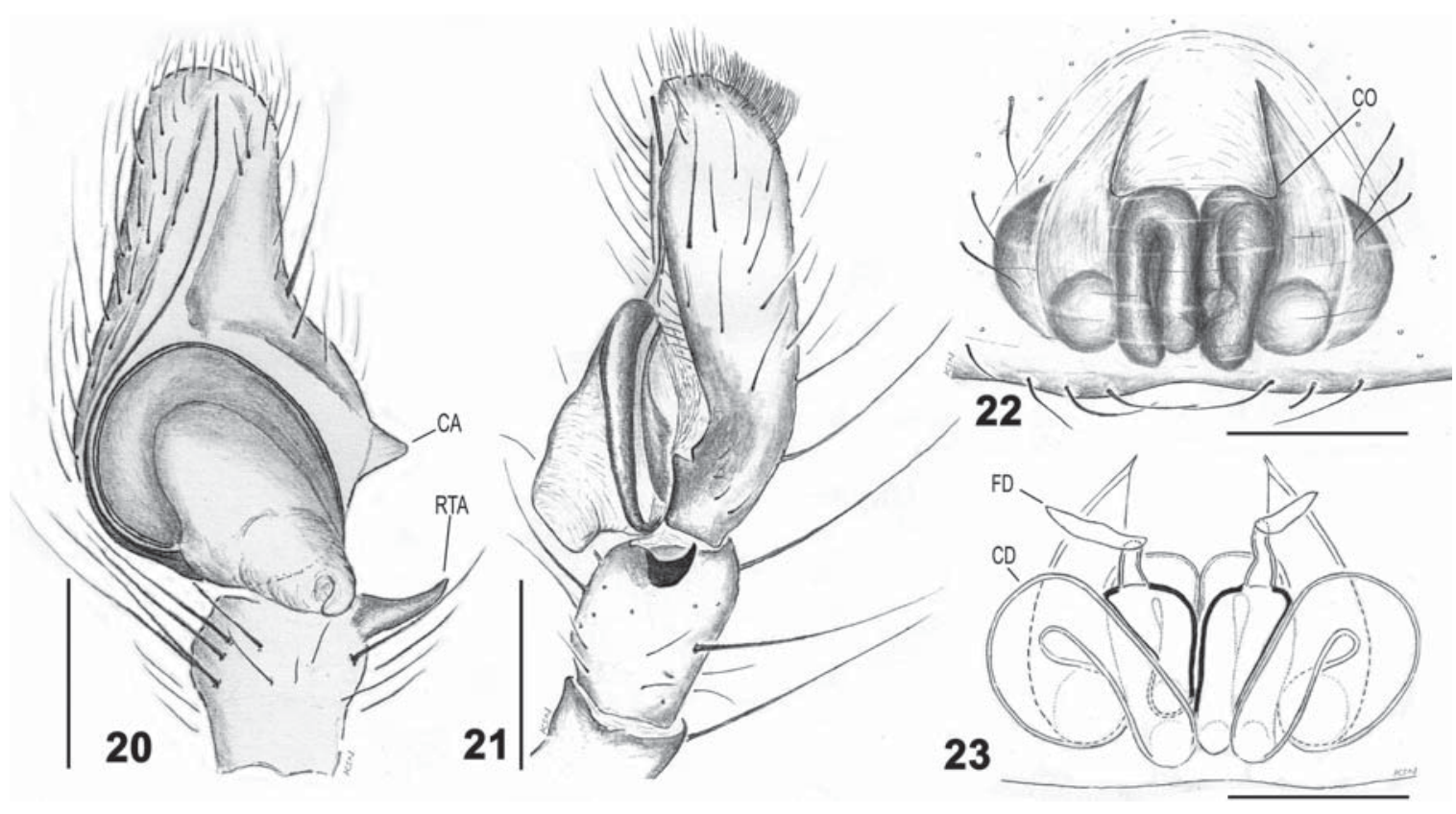

Figs 20-23. Copulatory organs of Epeus triangulopalpis sp.n., holotype male (20,21) and paratype female (22, 23): 20 - male palp, ventral view; 21 - ditto, retrolateral view; 22 - epigyne, ventral view; 23 - spermathecae, dorsal view. Scale bars: (20-21) $0.5 \mathrm{~mm}$, (22-23) $0.1 \mathrm{~mm}$

Abbreviations: $\mathrm{CA}$ - cymbial apophysis, $\mathrm{CD}$ - insemination duct, $\mathrm{CO}$ - copulatory opening, FD — fertilisation duct, RTA retrolateral tibial apophysis.

Рис. 20-23. Копулятивные органы Epeus triangulopalpis sp.n., самец-голотип $(20,21)$ и самка-паратип $(22,23): 20$ - пальпа самца, вид снизу; 21 - то же, сбоку-сзади; 22 - эпигина, вид снизу; 23 - сперматека, вид сверху. Масштаб: (20-21) 0,5 мм, (2223) 0,1 мм.

Сокращения: $\mathrm{CA}$ - отросток цимбиума, $\mathrm{CD}$ - осеменительный канал, $\mathrm{CO}$ - копулятивное отверстие, $\mathrm{FD}$ - оплодотворительный канал, RTA - отросток голени.

absent from E. alboguttatus) (cf. Figs 1-3, 8-11, 20, 21, 23 with figs 109-114, 116-120 in Żabka [1985]).

DESCRIPTION. MaLe (Holotype; Figs 1-3, 7-12, 20, 21). Measurements. Body length: 4.6. Carapace: 2.0 long, 1.8 wide, 1.2 height. Abdomen: 2.6 long, 1.1 wide, 0.8 height. Clypeus: 0.5 height. Chelicerae: 1.5 long. Eyes diameters: AME 0.51. ALE 0.19. PME 0.08. PLE 0.35. Eye interdistances: AME-AME 0.11. AME-ALE 0.18. PMEPLE 0.24. PME-PME 1.82. AME-PME 0.50.

Measurements of palp and leg segments

$\begin{array}{lccccc}\text { Leg segments } & \text { I } & \text { II } & \text { III } & \text { IV } & \text { Palp } \\ \text { Femur } & 1.60 & 1.75 & 2.22 & 1.63 & 0.73 \\ \text { Patella } & 0.62 & 0.51 & 0.62 & 0.56 & 0.27 \\ \text { Tibia } & 1.37 & 1.40 & 1.50 & 1.34 & 0.23 \\ \text { Metatarsus } & 1.10 & 1.21 & 1.60 & 1.50 & - \\ \text { Tarsus } & 0.65 & 0.50 & 0.60 & 0.62 & 0.64 \\ \text { Total } & 5.34 & 5.37 & 6.54 & 5.65 & 1.87\end{array}$

Carapace pale yellow-brown, covered with colourless setae; head pale, with white mottling, adorned with lustrous white scales. Eye field covered with red-orange scales, starting from dorsolateral AMEs to some extend behind PLEs, flanked by a band of white scales laterally, posteriorly with a thin transverse band of greenish yellow scales bend anteriorly, AME rims dark brown, encircled by predominantly white setae and red orange setae in the region between AMEs and ALEs and below AMEs, the area behind ALEs black, PME situated almost on the edge of the black area, the region around PLEs black, thin band of white scales surrounds ALEs and PLEs on lateral sides. Clypeus covered with white scales in the middle, the mid-lower margin with long white setae, with two vertical black markings continuous with those of chelicerae, covered with black scales, the area beneath AMEs covered with reddish orange scales. Sternum sub-pentagonal, pale yellow-brown, covered with colourless setae. Endites and labium yellowish red-brown, endites with black margins. Chelicerae slender and vertical, yellow-brown with black vertical markings; promargin with two teeth and retromargin with one tooth. Legs long and slender, banded with white and red-orange scales, coxae and most of the femora pale yellow-brown, apical regions of femora yellowbrown, tibiae, metatarsi and tarsi of legs I, II \& III yellowbrown and that of leg IV paler than the rest, legs covered with colourless and black setae, femora I-III with black longitudinal bands on their prolateral sides, such band is absent from femur IV, distal half of prolateral sides of femora I \& II covered with reddish orange and white scales, proximal and distal parts of tibiae and metatarsi I-III darker, covered with black setae and red-orange scales. Tibia I \& II with three pairs of ventral spines and metatarsi I \& II with two pairs of ventral spines. Abdomen cylindrical, yellowbrown, dorsum adorned with greenish yellow and black scales, covered with long setae, margins with four pairs of white spots made of white scales, the space between the markings black, also covered with dark scales; the posterior midline with three indistinct black patches; venter pale yellow-brown, with longitudinal black mottling. Anterior lateral spinnerets and posterior lateral spinnerets black, the rest of the spinnerets yellow-brown and covered with white scales. 


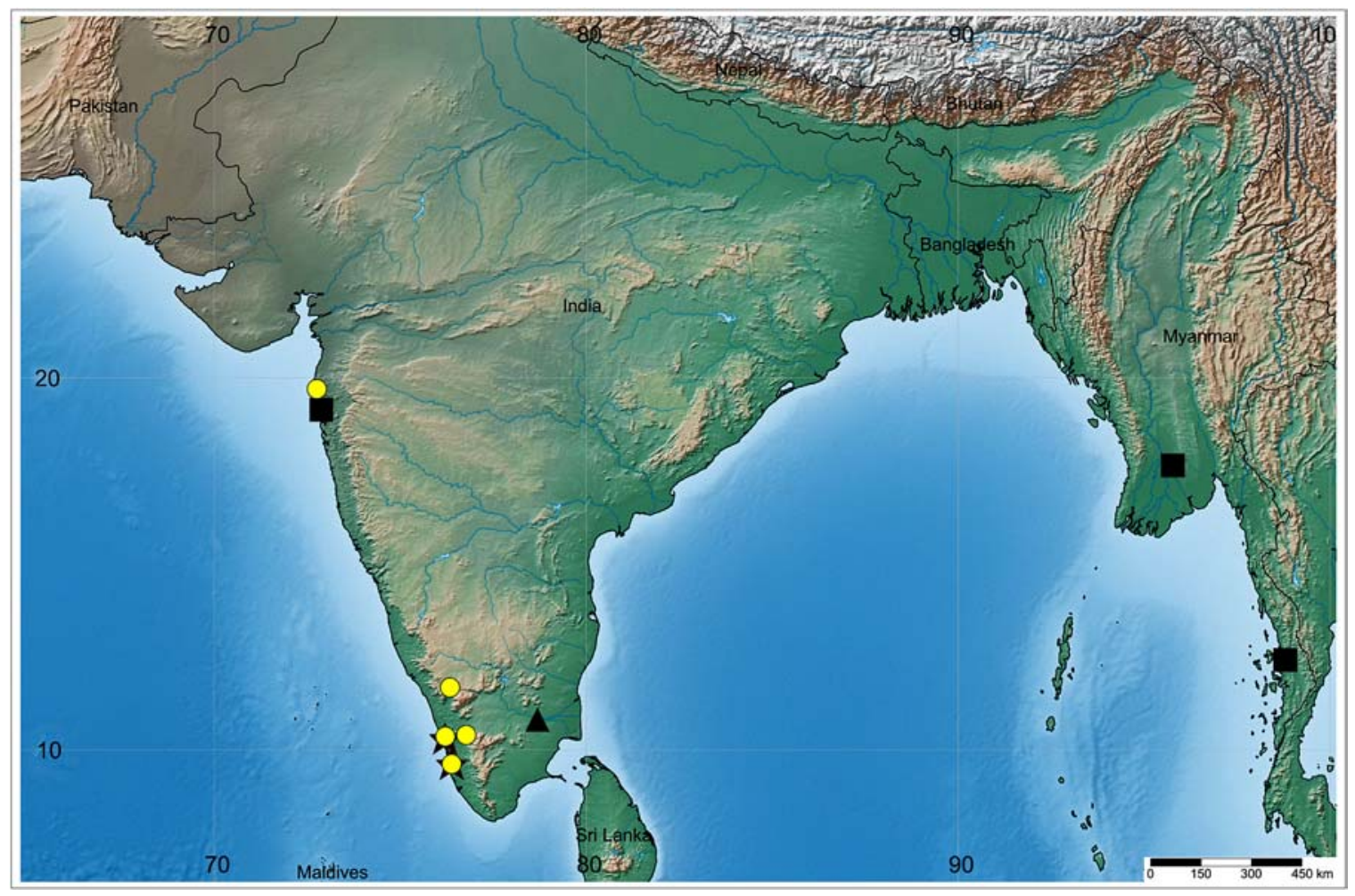

Map. Collecting localities of Epeus triangulopalpis sp.n. (circle) and all the Piranthus species: star - P. planolancis sp.n.; triangle P. casteti Simon, 1900; square - P. decorus Thorell, 1895.

Карта. Точки находок Epeus triangulopalpis sp.n. (кружок) и всех видов Piranthus: звезда — P. planolancis sp.n.; треугольник P. casteti Simon, 1900; квадрат — P. decorus Thorell, 1895.

Palp as shown in Figs 11, 12, 20, 21; palp pale yellow, except for yellowish brown cymbium; retrolateral tibial apophysis long and comma-like, apically bent anteriad, its tip pointed retro-laterad; cymbial apophysis triangular, projecting laterad; the posterior part of tegulum elevated, with a pooly visible tongue-like flap and drawn back ventro-retrolaterad over the tibia; embolus filiform, originates at eight o'clock and extends to the distal end of cymbium.

Female (paratype, Figs 4, 5, 13-19, 22, 23). Measurements. Body length: 6.4. Carapace: 2.2 long, 2.7 wide, 1.4 height. Abdomen; 4.2 long, 1.6 wide, 1.5 height. Clypeus: 0.6 height. Chelicerae: 1.8 long. Eyes diameters: AME 0.58 ALE 0.27. PME 0.10. PLE 0.2. Eye interdistances: AMEAME 0.14. AME-ALE 0.22. PME-PLE 0.27. PME-PME 1.4. AME-PME 0.61.

Measurements of leg segments

$\begin{array}{lcccc}\text { Leg segments } & \text { I } & \text { II } & \text { III } & \text { IV } \\ \text { Femur } & 2.04 & 2.27 & 2.56 & 1.94 \\ \text { Patella } & 0.82 & 0.93 & 0.90 & 0.72 \\ \text { Tibia } & 1.74 & 1.76 & 1.60 & 1.60 \\ \text { Metatarsus } & 1.60 & 1.40 & 2.07 & 1.69 \\ \text { Tarsus } & 0.71 & 0.73 & 0.75 & 0.62 \\ \text { Total } & 6.91 & 7.09 & 7.78 & 6.57\end{array}$

Carapace yellow-orange, covered with colourless setae, head light yellow-orange. Eye field covered with red-orange scales, starting from dorsolateral AMEs to some extend behind PLEs, it is flanked by white scales on the lateral sides, AME borders reddish brown, encircled by white setae except on the dorsolateral and lower AME-AME giving it an eyebrow-like appearance; the area around ALEs black, PMEs situated almost on the edge of the black area, the region around PLEs black, thin band of white scales surrounds ALEs and PLEs on the lateral sides; the posterior part of the head with an indistinct transverse band of white scales. Clypeus covered with white setae, its upper-mid region adorned with red orange scales and long setae. Sternum yellow orange, sub-pentagonal. Labium red-orange, endites light red-orange. Chelicerae yellow-orange. Femora and patellae of legs I-IV yellow-orange, femora I \& II with a prolateral black spot on their distal ends, tibiae, metatarsi and tarsi of legs I-III yellow-brown and that of leg IV light yellow-brown, white scales present on tibiae, metatarsi \& tarsi I-III, basal and the apical parts of tibiae and metatarsi I \& II lateral black spots, black spots present only on tibiae III \& IV and is absent from the retrolateral side of the basal tibia. Tibiae I \& II with three pairs of ventral spines and metatarsi I \& II with two pairs of ventral spines. Palpal femur and patella yellow-orange, the remaining segments yellow-brown. Abdomen oblong, pale yellow, posteriorly with two distinct and three indistinct black markings, marginally with four pairs of white markings made of white scales, yellow scales are present in the region around the black markings and between the white markings. Spinnerets long and black, anterior lateral and posterior lateral spinnerets with white scales. Epigyne and spermathecae as shown in Figs 18, 19, 22, 23; the sclerotised rim of the epigynal opening in the anterior half of the epigyne; no epigynal pockets; insemination duct large, forming a large loop laterally, posteriorly entering and forming an elongated loop and finally entering the receptacles posteriorly. 


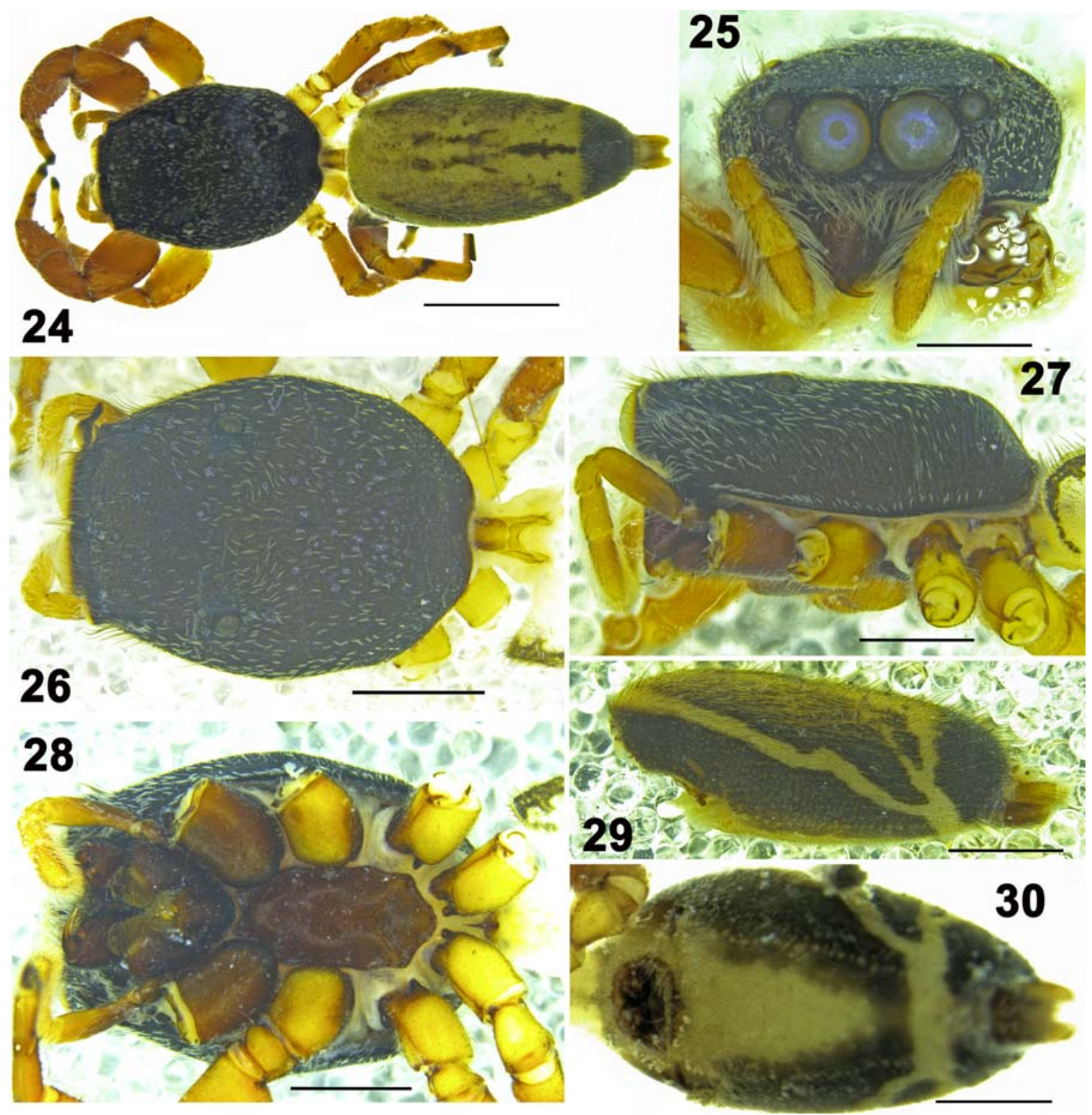

Figs 24-30. The holotype female of Piranthus planolancis sp.n.: 24 - general appearance, dorsal view; 25 - carapace, frontal view; 26 - ditto, dorsal view; 27 - ditto, lateral view; 28 - ditto, ventral view; 29 - abdomen, lateral view; 30 - ditto, ventral view. Scale bars: (24) $2 \mathrm{~mm},(25-30) 1 \mathrm{~mm}$.

Рис. 24-30. Самка-голотип Piranthus planolancis sp.n.: 24 - общий вид сверху; 25 - головогрудь, вид спереди; 26 - то же, сверху; 27 - то же, сбоку; 28 - то же, снизу; 29 - брюшко, вид сбоку; 30 - то же, снизу. Масштаб: (24) 2 мм, (25-30) 1 мм.

HABITUS OF LIVE SPECIMENS (Figs 1-5). Live specimens of both sexes are very colourful, having a yellowish green colour. The eye field laterally bordered by red-orange bands, which are flanked by white scales on their sides, and with a white trianglular patch on the clypeus (Fig. 3); the upper and lower regions of the eyes with white scales. All legs with alternative dark red-orange and white bands, the prolateral side of all femora with a black patch. Abdomen with four pairs of prominent white spots. Cymbium of the male palp dark red-orange, with long white hairs anteriorly. All femora and patellae in the female yellowish green, tibiae to tarsi with alternative pale black and white bands. Abdomen possesses five pairs of white patches and four black patches in its posterior half.
DISTRIBUTION. India: Kerala (Parambikulam, Pathiramanal Island, Irinjalakuda and Wayanad) (Map).

Piranthus Thorell, 1895

Type species: Piranthus decorus Thorell, 1895.

Piranthus planolancis sp.n.

Figs 6, 24-38, Map.

TYPES. Holotype 9 (ADSH 8744003A) from India, Kerala, Pathiramanal Island $\left(9^{\circ} 37^{\prime} 07.11^{\prime \prime} \mathrm{N}, 76^{\circ} 23^{\prime} 04.95^{\prime \prime}\right), 4 \mathrm{~m}$. a.s.1., from foliage by hands, 16.08 .2015 , M.J. Jobi \& M.S. Pradeep. PARA- 

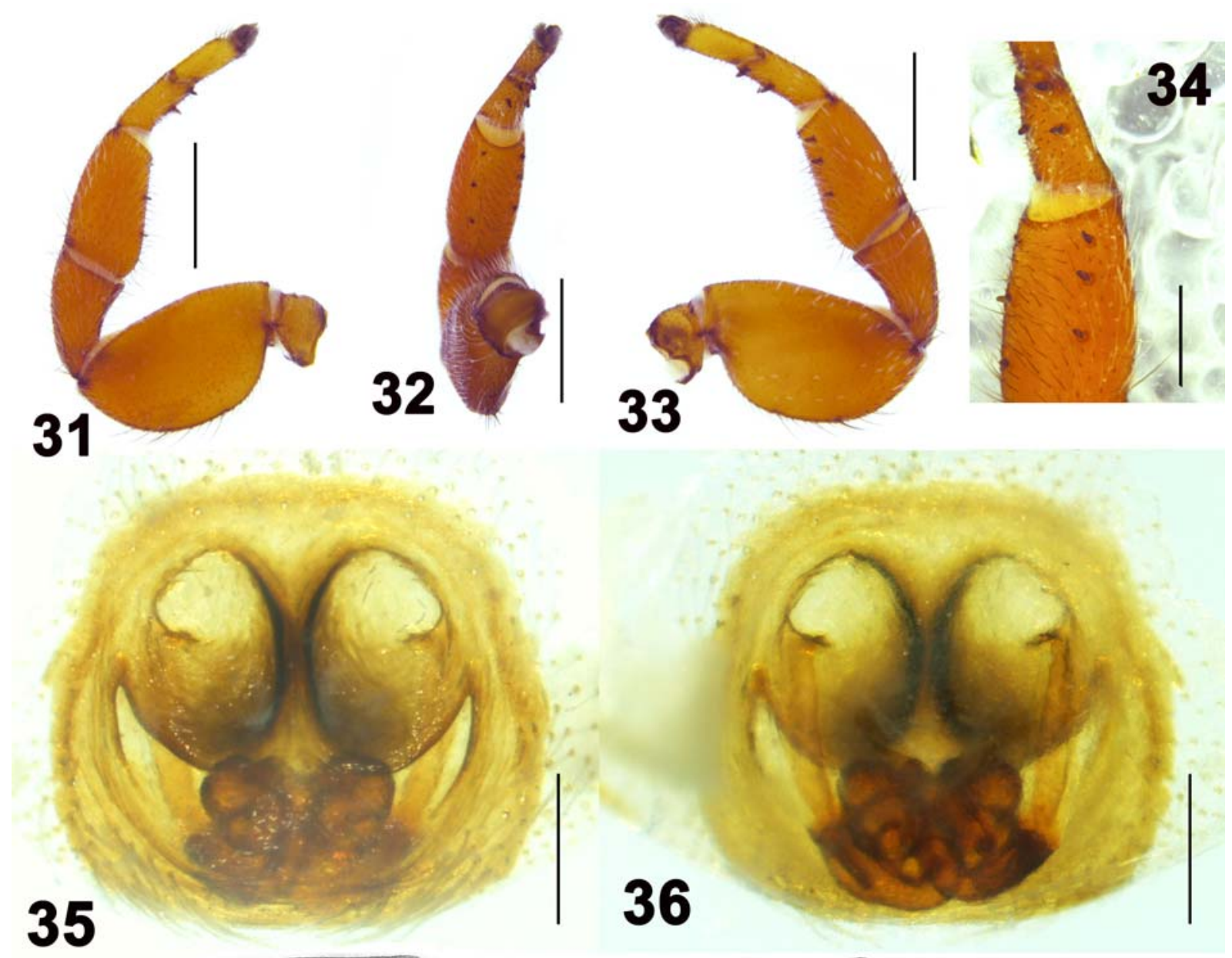

\section{6}

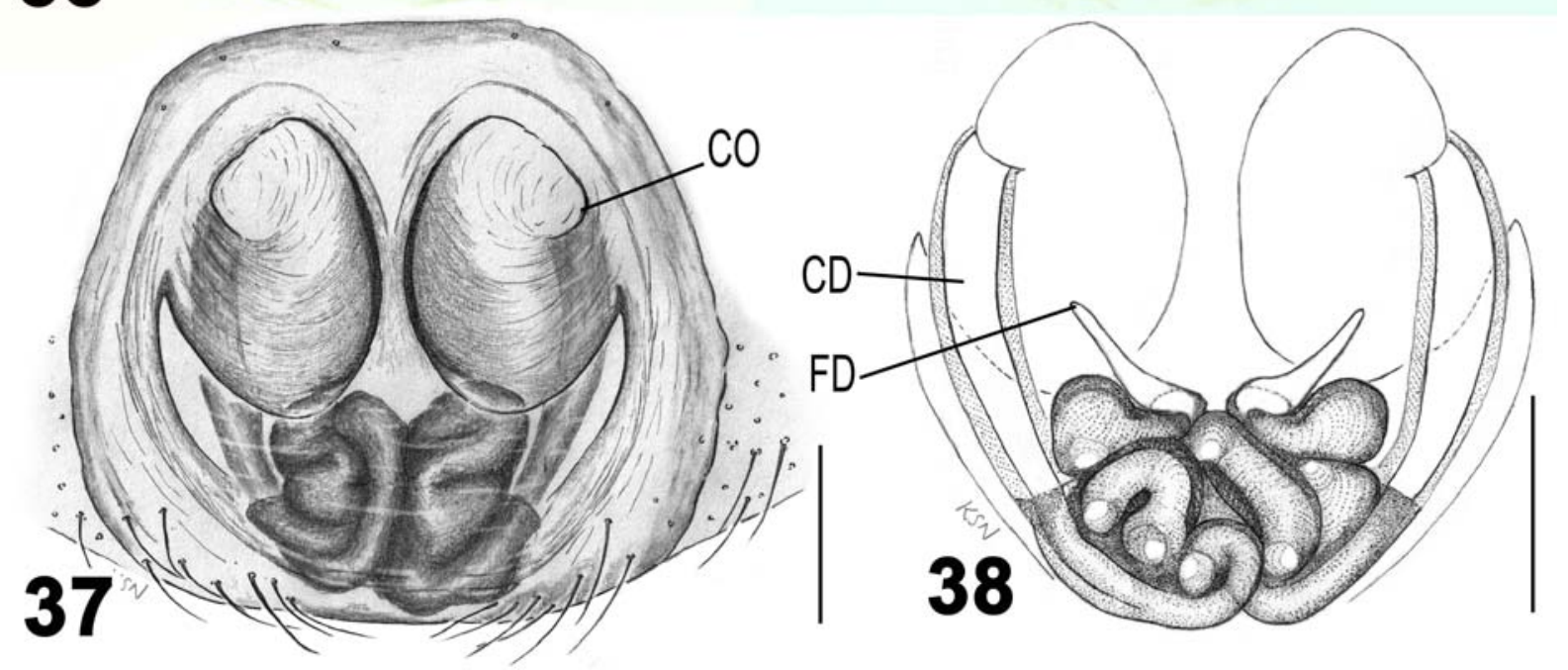

Figs 31-38. The holotype female of Piranthus planolancis sp.n.: 31 - left leg I, prolateral view; 32 - ditto, ventral view; 33 - ditto, retrolateral view; 34 - ditto, a close up image showing the short spines; 35,37 - epigyne, ventral view; 36, 38 - spermathceae, dorsal view. Scale bars: (31-33) $1 \mathrm{~mm},(34) 0.5 \mathrm{~mm},(35-38) 0.25 \mathrm{~mm}$.

Abbreviations: $\mathrm{CD}$ - insemination duct, $\mathrm{CO}$ - copulatory opening, $\mathrm{FD}$ - fertilisation duct.

Рис. 31-38. Самка-голотип Piranthus planolancis sp.n.: 31 - левая нога I, вид спереди-вбоку; 32 - тоже, снизу; 33 - тоже, сзади-сбоку; 34 - тоже, увеличенное изображение коротких шипов; 35,37 - эпигина, вид снизу; 36,38 - сперматека, вид сверху. Масштаб: (31-33) 1 мм, (34) 0,5 мм, (35-38) 0,25 мм.

Сокращения: $\mathrm{CD}$ - осеменительный канал, $\mathrm{CO}$ - копулятивное отверстие, $\mathrm{FD}$ - оплодотворительный канал. 


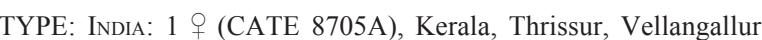
$\left(10^{\circ} 18^{\prime} 24.4^{\prime \prime} \mathrm{N}, 76^{\circ} 12^{\prime} 16.1^{\prime \prime} \mathrm{E}\right), 10 \mathrm{~m}$ a.s.1., 12.2017, Varun Das \& K.S. Nafin.

ETYMOLOGY. The specific epithet derives from the Latin words plano (= flat) and lancis (= plate) and refers to the plain posterior median plate of the epigyne.

DIAGNOSIS. The new species is strikingly similar to $P$. decorus, but can be easily distinguished from it by the following characters: the posterior plate of the epigyne without the epigynal pocket (present in $P$. decorus); the major axis of the epigynal oval groves parallel to each (major axis at approximately a 45 degrees angle anteriorly in $P$. decorus); insemination ducts highly convoluted and larger (smaller and markedly less convoluted in P. decorus) (cf. Figs 35-38 with figs 2E, F \& 3A, B in Caleb \& Sanap [2017]).

DESCRIPTION. MALE unknown.

Female (holotype; Figs 6, 24-38). Measurements. Body length: 9.5. Carapace: 5.6 long, 3.7 wide, 0.8 height. Abdomen: 3.9 long, 2.3 wide, 1.2 height. Clypeus: 0.2 height. Chelicerae: 1.4 long. Eyes diameters: AME 0.71. ALE 0.32. PME 0.10. PLE 0.23. Eye interdistances: AME-AME 0.71. AME-ALE 1.2. PME-PLE 1.69. PME-PME 1.92.

Measurements of leg segments:

$\begin{array}{lcccc}\text { Leg segments } & \text { I } & \text { II } & \text { III } & \text { IV } \\ \text { Femur } & 1.5 & 1.3 & 1.3 & 1.6 \\ \text { Patella } & 0.9 & 0.7 & 0.5 & 0.6 \\ \text { Tibia } & 1.0 & 0.9 & 0.7 & 1.0 \\ \text { Metatarsus } & 0.6 & 0.6 & 0.7 & 1.1 \\ \text { Tarsus } & 0.5 & 0.5 & 0.6 & 0.4 \\ \text { Total } & 4.5 & 4.0 & 3.8 & 4.7\end{array}$

Carapace black, rugose, covered with setae and scattered white scales, widest in the middle, top flat, posteriorly abruptly sloping, the posterior border curved inwardly. Eye field wider than long; AMEs and ALEs surrounded by setae, PMEs minute, located one third the distance from ALEs and PLEs, ALEs slightly bigger than PLEs, the inner margin of PLE slightly elevated. Clypeus short, covered with setae and lower margin with long white setae. Sternum reddish brown, longer than wide. Endites and labium dark brown. Chelicerae pluridentate, promargin with three teeth and retromargin with 6-8 teeth. Legs robust, legs I enlarged, with massive flattened, deep orange femora (Figs 31-34), other legs yellowish orange, femora II and III flattened, a gap between coxae II and III, coxae III and IV with a basal notch, tibiae I and metatarsi I with three and two pairs of very short, stout ventral spines respectively, tibia II ventrally with a tiny stout spine and metatarsus II with two pairs of short stout spines. Abdomen long and cylindrical, covered with long dark setae and black and cream scales, two pairs of sigillae present; dorsum creamy, with a tuning fork-like dark marking along the longitudinal midline, flanked by lateral black mottling, the posterior fifth black; sides mostly black, with a prominent diagonal creamy band from antero-dorsal to posteroventral parts of the abdomen; three fourth of the venter creamy, tapering towards the posterior part, which has a wide transverse creamy band. Epigyne and spermathecae as shown in Figs 35-38; highly sclerotised, copulatory openings situated antero-laterally in the prominent oval grooves occupying almost a half of the anterior part of the epigyne, separated by a thin median septum; the posterior plate of the epigyne flat, slightly sloping anteriorly, bordered with a sclerotised rim forming a pocket at postero-lateral side of the anterior groves; insemination ducts long, entering the highly convoluted spermathecal canals posteriorly, oval receptacles are located anteriorly; fertilisation ducts are situated anteriorly.
DISTRIBUTION. India: Kerala (Pathiramanal Island and Vellangallur) (Map).

\section{Discussion}

The jumping spider genus Epeus currently consists of 15 valid species, known predominantly from SE Asia [WSC, 2018]. However, the majority of Epeus species remain known from a single sex only. The new species, E. triangulopalpis sp.n., is described from both sexes, being the sixth Epeus species known from both sexes. To date, only three species - Epeus albus Prószyński, 1992, E. chilapataensis (Biswas et Biswas, 1992) and E. indicus Prószyński, 1992 - have been reported from India and all are known from the females. Yet, Dhali et al. [2010] mentioned Epeus edwardsi Barrion et Litsinger, 1995 in a spider checklist of the State of West Bengal in India, but they failed to provide any proof of their record such as illustrations or photographs.

The genus Piranthus was erected more than a hundred years ago [Thorell, 1895], but it still remains with a nominal representation of two species known from India and Myanmar only [Caleb, Sanap, 2017]. Amongst these two species, $P$. casteti Simon, 1900 is unique to India, whereas $P$. decorus was originally described from Myanmar, but then was found in India by Caleb \& Sanap [2017], 122 years after its original description. Both these species remain known from the females only, with no new Piranthus species having been added to date. Here we have reported on and described a new $P$. planolancis sp.n., also based on the female. Its diagnostic features (especially the structure of female copulatory organs) are distinctive, and the identification of this species will not be a problem in the future. As the conformation of the epigyne of $P$. casteti is markedly different from those of two other congeners (see Prószyński [1987: 78]), it is likely that the latter species could belong to a different genus; this matter is outside the scope of the present study.

Acknowledgements. We are grateful to the Rev. Fr. Prasanth Palackappillil CMI, Principal, Sacred Heart College, Thevara, Cochin, and the late Fr. Jose Thekkan, former Principal, Christ College, Irinjalakuda, Kerala for providing us with all the research facilities to undertake this study. We wish to acknowledge the massive effort of the World Spider Catalog team in making the spider data available to araneologists worldwide. Special thanks go to Dr Dmitri Logunov (Manchester, UK) for his comments on the ms and editorial help. We are thankful to Jerzy Prószyński (Warsaw, Poland) for his valuable comments and encouragement. We are indebted to Mr John T.D. Caleb of the Zoological Survey of India for sharing his views on the new Piranthus species. Dr Atul Vartak (Maharashtra, India) is greatly appreciated for his excellent live photographs.

\section{References}

Caleb J.T.D., Sanap R.V. 2017. Rediscovery of Piranthus decorus Thorell 189 (Araneae:Salticidae) after 122 years since the orig- 
inal description // Acta Arachnologica. Vol.66. No.1. P.25-29.

Dhali D.C., Sen S., Saha S., Raychaudhuri D. 2010. Jumping spiders (Araneae: Salticidae) of four reserve forests of Dooars, West Bengal // Bionotes. Vol.12. No.1. P.24-25.

Meng X.W., Zhang Z.S., Shi A.M. 2015. Description of two unknown females of Epeus Peckham \& Peckham from China (Araneae: Salticidae) // Zootaxa. Vol.3955. No.1. P.147-150.

Peng X.J., Li S.Q. 2002. A review of the genus Epeus Peckham et Peckham (Araneae: Salticidae) from China // Oriental Insects. Vol.36. P.385-392.

Prószyński J. 1987. Atlas rysunków diagnostycznych mniej znanych Salticidae 2 // Zeszyty Naukowe Wyższej Szkoly Rolniczo-
Pedagogicznej v Siedlcach. P.1-172

Thorell T. 1895. A descriptive catalogue of the spiders of Burma. London. $406 \mathrm{p}$.

Simon E. 1900. Descriptions d'arachnides nouveaux de la famille des Attidae // Annales de la Société Entomologique de Belgique. Vol.44. P.381-407.

WSC 2018. World Spider Catalog. Natural History Museum Bern, online at http:// wsc.nmbe.ch, version 19.5. (accessed 30 October 2018).

Żabka M. 1985. Systematic and zoogeographic study on the family Salticidae (Araneae) from Viet-Nam // Annales Zoologici, PAN. T.39. P.197-485. 